DOI: http://dx.doi.org/10.18203/2320-1770.ijrcog20180926

Case Report

\title{
Iniencephaly: a rare birth defect
}

\section{Alpana Singh, Vasudha Gupta*, Amrita}

Department of Obstetrics and Gynecology, UCMS and GTB Hospital, Delhi, India

Received: 16 December 2017

Accepted: 20 January 2018

\section{*Correspondence:}

Dr. Vasudha Gupta,

E-mail: vasudhamamc@gmail.com

Copyright: (c) the author(s), publisher and licensee Medip Academy. This is an open-access article distributed under the terms of the Creative Commons Attribution Non-Commercial License, which permits unrestricted non-commercial use, distribution, and reproduction in any medium, provided the original work is properly cited.

\begin{abstract}
Iniencephaly is form of neural tube defect which includes occipital bone defect at foramen magnum along with fixed retroflexion of fetal head and absence of fetal neck. Incidence of iniencephaly is 0.1-10 in 10,000 pregnancies. There is a known female predilection for this condition. Iniencephaly has a poor prognosis. It can be diagnosed antenatally by raised maternal serum alpha-fetoprotein and typical ultrasound features. Termination should be advised to patients who present before 20 weeks. Herein we are describing a case of iniencephaly who presented at 27 weeks of gestation with a brief review of literature.
\end{abstract}

Keywords: Anencephaly, Iniencephaly, Retroflexion

\section{INTRODUCTION}

Iniencephaly is a rare form of neural tube defect characterized by occipital bone defect at foramen magnum along with retroflexion of fetal head and absence of fetal neck. This disorder leads to extreme retroflexion that means backward bending of the head along with distortion of the spine. Face of the baby look upwards due to extreme retroflexion. Incidence is $0.1-10$ in 10,000 pregnancies. ${ }^{1}$ Exact etiology of iniencephaly is not known, but various genetic and environmental factors are proposed. Recurrence risk is 1 to $5 \%$. Patients with iniencephaly in previous baby should be advised to take folic acid for three months in periconceptional period. Iniencephaly was reported by Saint Hilaire. ${ }^{2}$ Iniencephaly is subdivided in two types: iniencephaly apertus and iniencephaly clausus. We are describing a case of iniencephaly clausus.

\section{CASE REPORT}

A 27-year-old lady $\mathrm{G}_{7} \mathrm{P}_{2} \mathrm{~L}_{1} \mathrm{~A}_{4}$ at 27 weeks period of gestation with non-consanguineous marriage with previous two LSCS presented to gynecological OPD along with an ultrasound report showing multiple gross congenital anomalies. First ultrasound was done at 26 weeks. Ultrasound showed gross multiple brain and spinal deformities including spina bifida, AFI was $12 \mathrm{~cm}$.

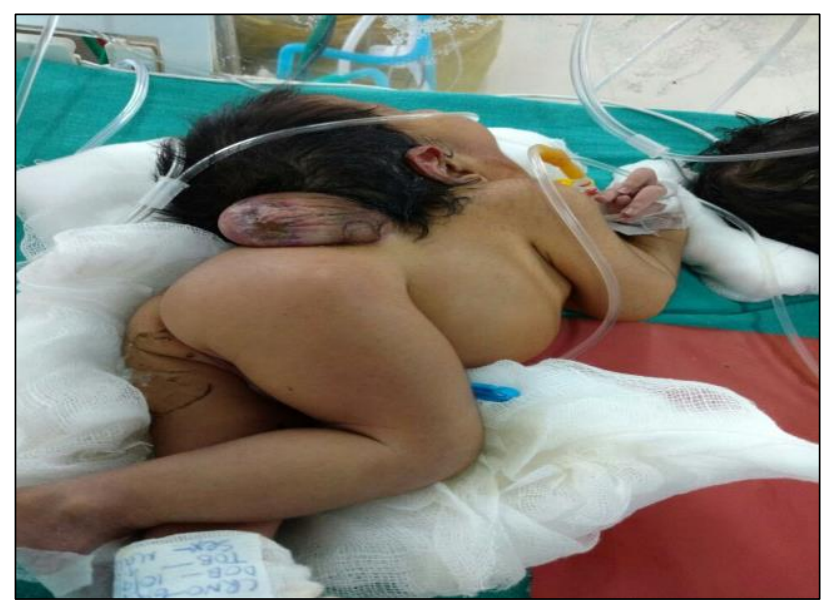

Figure 1: Photograph of baby showing fixed retroflexion, absent neck and meningomyelocele. 


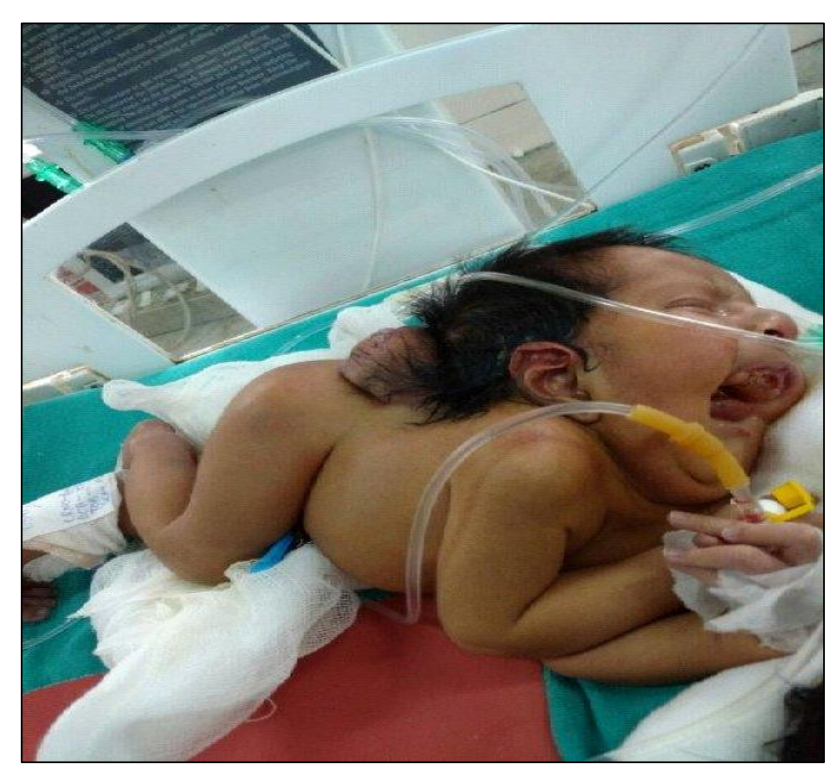

Figure 2: Photograph of baby showing high arched palate, fixed retroflexion, absent neck and thoracic meningomyelocele.

There was no history of folic acid intake in preconception and antenatal period. Rest antenatal investigations were normal. At 39 weeks period of gestation the same patient presented to gynecological emergency department with pain abdomen and with transverse lie. An emergency LSCS was done and $2.3 \mathrm{~kg}$ male baby was delivered with fixed retroflexion of head, high arched palate and thoracic unruptured meningomyelocele of $4 \mathrm{~cm} \times 3 \mathrm{~cm}$. Head circumference was $31 \mathrm{~cm}$ (Figure 1 and 2). Patient had polyhydramnios around 2.5 litres of amniotic fluid was drained. Baby had respiratory difficulty, so he was shifted to nursery on oxygen where he was kept on intravenous fluids and oxygen. Baby expired on third day despite resuscitation. Patient and her family refused autopsy of baby.

\section{DISCUSSION}

Iniencephaly is a word derived from word "inion" which means back of head and encephalos which means brain. It is a rare neural tube defect characterized by

- Defect in occipital bone

- Either partial or total absence of cervicothoracic vertebrae

- Fixed fetal head retroflexion. Iniencephaly was reported by Saint Hilaire. ${ }^{2}$

Fetus is described to have a stargazer type extended posture on antenatal ultrasound. There is a recognized female predilection. ${ }^{3}$ Hernando et al also reported a similar case of iniencephaly delivered at 37 weeks with fixed fetal head retroflexion, macrocephaly, marked lordosis and thoracolumbar spina bifida with meningomyelocele. ${ }^{1}$ But there is marked fixed retroflexion, high arched palate and thoracic meningomyelocele in the present case report compared to theirs.

Exact etiology of this condition is not known. Environmental factors proposed are low socioeconomic status, lack of folic acid intake, obesity, drugs like sulfonamides, tetracyclines, antihistaminics and hyperhomocystenemia. ${ }^{4}$ The genetic factors proposed are monosomy X, trisomy 18 and Turner's syndrome. ${ }^{5}$

The defects in iniencephaly occur very early in the pregnancy before closure of cephalic neural fold at 24 days of gestational age. The paravertebral mesoderm differentiates into two parts. The ventral part forms the vertebral bodies, pedicles, and cranial homologues. Dorsal part forms the neural arches and cranial vault bones. In iniencephaly, there is malformation of one or both the masses. Neural tube closure is a multisite initiation process and five closure sites are proposed mid cervical, between prosencephalon and mesencephalon, stomodeum, site, caudal end of rhombencephalon, and caudal end of neural tube. Iniencephaly occurs due to defective closure at mid cervical and caudal end of rhombencephalon. ${ }^{6}$

Iniencephaly is subdivided into two types by Lewis Iniencephaly apertus-associated with encephalocele and iniencephaly clausus-associated with spinal defects. Further Hawkins and Lawrie classified iniencephaly in which apertus and clausus were included and iniencephaly with anencephaly was also added (anencephaly with spinal retroflexion)., ${ }^{7,8}$

Iniencephaly can be diagnosed antenatally by increased maternal serum alpha fetoprotein in first and second trimester and typical ultrasound features-fixed stargazer type extended posture, exaggerated cervicothoracic lordosis, deficient or fused cervical vertebrae, fetal crown lump length less than that of expected gestational age, associated polyhydramnios as done by Singh et al. ${ }^{9}$ CT scan and MRI are also diagnostic for iniencephaly and both are equally sensitive but are expensive investigations. Singh et al reported a case of iniencephaly which was diagnosed at 18 weeks by ultrasonography and MTP was done. ${ }^{9}$

Differential diagnosis for this condition are physiological cervical hyperextension, Klippel Feil syndrome, anencephaly with spinal retroflexion, nuchal tumours such as teratomas, lymphangiomas and Jarcho Levin syndrome. ${ }^{5}$

16 cases of iniencephaly at early gestation were reported by Eken et al and correlation was done between sonographic and pathological findings. They found that anencephaly was the most common anomaly associated with iniencephaly in the first trimester. Other associated systemic anomalies include: cardiovascular anomalies, diaphragmatic hernias, gastrointestinal malformations, hypoplastic lungs, cerebellar hypoplasia, single umbilical 
artery, encephalocele, meningomyelocele, hydrocephalus, dandy walker malformation, holoprosencephaly, omphalocele, hydronephrosis, polycystic kidneys, caudal regression syndrome, arthrogryposis, club foot, gastrointestinal atresia. ${ }^{10}$

In this case the anomalies in baby are, fixed retroflexion of head, high arched palate and thoracic meningomyelocele and polyhydramnios. These findings are consistent with Iniencephaly clausus.

Iniencephaly can lead to obstructed labour. Risk of recurrence in next pregnancy is $1-5 \%$. Iniencephaly has a very bad prognosis and is a fatal condition. ${ }^{11}$

\section{CONCLUSION}

Iniencephaly is a rare fatal NTD, that occurs due to the defective neural tube closure at sites mid cervical and caudal end of rhomboencephalon. Because the condition is incompatible with life, careful and early USG diagnosis is required so that termination can be offered to the parents. CT and MRI are equally sensitive as autopsy in diagnosis of iniencephaly.

Funding: No funding sources

Conflict of interest: None declared

Ethical approval: Not required

\section{REFERENCES}

1. Alvis-Miranda HR, Bula-Anichiarico DA, CalderónMiranda WG, Moscote-Salazar LR. Iniencephaly: Case Report J Pediatr Neurosci. 2015;10(2):181-4.
2. Sainit-Hilaire IG. Iniencephalus In: Bailliere JB, ed. History of the Anomalies of the Organization Paris; 1836:308-10.

3. Pungavkar SA, Sainani NI, Karnik AS, Mohanty PH, Lawande MA, Patkar DP, et al. Antenatal diagnosis of iniencephaly: sonographic and MR correlation: a case report. Korean J Radiol. 2007;8(4):351-5.

4. Joó JG, Beke A, Papp C, Szigeti Z, Csaba A, Papp Z. Major diagnostic and pathological features of iniencephaly based on twenty-four cases. Fetal Diagn Ther. 2008;24(1):1-6.

5. Kulkarni PR, Rao RV, Alur MB, Joshi SK. Iniencephaly clausus: a case report with review of literature. J Pediatr Neurosci. 2011;6(2):121-3.

6. Halder A, Pahi J, Pradhan M, Pandey A, Gujral R, Agarwal SS. Iniencephaly: a report of 19 cases. Indian Pediatr. 1998;35(9):891-6.

7. Lewis HL. Iniencephalus. Am J Obstet. 1897;35:1153.

8. Hawkins J, Lawrie R. Iniencephalus. J Obstet Gynecol Br Emp. 1939;46:26-31.

9. Singh A, Mundhra R, Manchandra S, Radhakrishnan G, Meena P. Early diagnosis of iniencephaly: a case report with review of literature. Int $\mathbf{J}$ Reprod Contracept Obstet Gynecol. 2015;4:2047-9.

10. Eken MK, Ilhan G, Ertekin AA, Kaygusuz EI, Sahinoglu Z, Herkiloglu D, et al. Iniencephaly in early gestation and accompanying ultrasonographic findings. J Cases Obstet Gynecol. 2016;3(2):72-6.

11. Romero R, Jeanty P, Pilu G, Ghidini A, Hobbins JC. Iniencephaly, In: Prenatal diagnosis of congenital anomalies. Appleton and Lange, Norwalk, Conn, USA; 1988:65.

Cite this article as: Singh A, Gupta V, Amrita. Iniencephaly: a rare birth defect. Int J Reprod Contracept Obstet Gynecol 2018;7:1236-8. 